\title{
Justice in post-apartheid South Africa: Towards a Theology of Restitution
}

T S Maluleke

(University of South Africa)

\section{ABSTRACT \\ Justice in post-apartheid South Africa: Towards a Theology of Restitution}

Having dabbled with the metaphors of liberation, reconstruction and reconciliation, the time may have come for (South) African prophetic theology to seriously consider the metaphor of restitution. In this essay, the author outlines the contours of a theology of restitution. The starting point is the existing but mostly unspoken theologies for and against various forms of restitution. An exploration of the contours of a theology of restitution is conducted. In order to illustrate the tasks and challenges of a theology of restitution - the author refers to the parable of Lazarus and the rich man. For him a credible theology of restitution is a theology capable of restoring Lazarus before not after he dies.

\section{BEWARE OF TOWARDS THEOLOGIES}

Mokgethi Motlhabi (1994) would not be amused with the title of my essay. He is especially perturbed by any theological essay which starts with the word "towards". Motlhabi's basic view is that the time for "towards theologies" and "introductions-to theologies" is past. Now is the time to get on with it, he insists. Having been part of that first generation of Black and African theologians who not only witnessed but also participated in the first tentative and foundational attempts to build "local theologies" (Schreiter 1985) Motlhabi can be pardoned for being a little impatient with "towards theologies". He was after all, a youngster when the likes of Bantu Biko (Biko 1988) and Sabelo Ntwasa were urging theology students to embark in something then called a "Black Theology of Liberation” (Mosala 1989). He read, at that time John Mbiti's (1966; 1970; 1986) spirited apologetics for a theologia Africana - a cause also taken up, even more polemically, by Gabriel Setiloane (1976). As a young participant in the first seminars and workshops on Black Theology, organised by the University Christian Movement of Basil 
Moore, Motlhabi listened to far too many "towards ... theology papers”.

Motlhabi's suspicion is that there is a sense in which our extended flirtations with "towards theologies" are a refuge within which we shirk our responsibility to get on with the job of putting forward something concrete on the table. "Towards theologies" are also a shock-absorber devise that anticipates and absorbs in advance whatever criticism we may encounter in response to our tentative theologies. The problem becomes acute when every other theologian and every other theological school presents "toward versions of theologies" each hoping that others will produce "real deal" theologies. Before we know it, we all become "towards theologians" and "towards theological communities" - producing theologies which are overly tentative, apologetic to the point of incoherence theologies which become inconsequential and not likely to be taken seriously.

Part of the problem with towards theologies is that behind most of them there is an element of dishonesty. Such dishonesty is because most of the theologies we are supposed to be constructing, or their opposites, actually exist already, in reality. Both the raw material and the "material conditions" necessary for the latent existence and construction of such theologies is often already there. Often, the initial theological task is one of unmasking the faces, phases and guises in which such theologies already "exist" in elementary forms. There is a classical "definition" of African theology by the late Henry Okullu (1974:54) of Kenya which illustrates this point well:

... when we are looking for African theology we should go first to the fields, to the village church, to the village church, to Christian homes to listen to those spontaneously uttered prayers before people go to bed. We should go to the schools, to the frontiers where traditional religions meet with Christianity. We must listen to the throbbing drumbeats and the clapping of hands accompanying the impromptu singing in the independent churches. . . . Everywhere in Africa things are happening. Christians are talking, singing, preaching, writing, arguing, praying, discussing. Can it be that all this is an empty show? It is impossible. This then is African theology. 
The suggestion here is that, once there were African adherents of the Christian faith, "African Theology" started existing, at least as a "lived and oral theology" long before the first article on African Theology was written; Black Theology existed a long time before it was called by name and Feminist Theology likewise (Maluleke 1995). That the first article on African Theology and the first book on Feminist Theology took so long before appearing is but a comment on our theological/intellectual astuteness/or lack thereof. These theologies did not start to exist the day theologians and researchers took notice; anymore than the Victoria Falls began to exist the day David Livingstone "discovered" and "named" them.

\section{EXPLORING RESTITUTION}

Our first challenge in the exploration of a theology of restitution is to recognise the theologies of restitution and the theologies of antirestitution which though often unspoken, are already in existence. This is the first and basic theological task, the first point of insertion in the hermeneutical cycle as we ponder over a theology of restitution.

But first I must formally make the proposal that at the beginning of the $21^{\text {st }}$ century, South Africa, Africa (continental and diaspora) is in need of a theology of restitution. We need a theology of restitution, not merely in response to the waves of independence that have swept through Africa since the 1950's (with South African independence [1994] being the most recent), but we need this theology in spite of the independence gained by African states. A theology of restitution is necessary not because of the South African Truth and Reconciliation Commission (TRC) but in spite of it (Maluleke 1997a). We need a theology of restitution not only because of the dire implications of neo-liberal economic policies that shape and define the world at the dawn of the $21^{\text {st }}$ century, but also because of their resonance with post-colonial and post-independence political economies. Unless we seriously consider and grapple with the question of restitution we will soon discover that many of the "victories" of the late twentieth century and those of the beginning of the twenty first - whose celebrations still echo in our hearts, will soon dissipate before our very own eyes, if they have not done so already.

Restitution is what should happen between people and land, between people and history, between people and their institutions as 
well as between people and their knowledges (Maluleke 2007). It is what needs to happen between men and women, men and men, women and women, blacks and whites, blacks and blacks as well as whites and whites.

The new and young South Africa is sometimes puzzling in its avoidance of discourse on some of the very issues which ought to be central to the unfolding story of its own birth. Such avoided issues include restitution, racism and violence. The word restitution is itself not preferred much in our land. As a country, South Africa's concept of choice is reconciliation - usually seen both as a means and as an end. It is a word that is more pleasing to our sensibilities. Not that there is anything intrinsically wrong with the wonderful (and Christian) notion of reconciliation. The Christian faith revolves around the realisation that God so loved the world that God has taken concrete and costly steps towards the world with a view to reconciling all creation to God's self. Yet, this term can be and has been grossly misunderstood, misappropriated and softened. Until now the notion of reconciliation appears to have been thoroughly abducted into the discourse of the ruling classes in South Africa. From this perspective reconciliation appears to be something which the powerless must do for the powerful; it seems to be a necessity for the wronged and an optional extra for beneficiaries and perpetrators; reconciliation comes across as some ritual to be performed by the poor; a rite for Blacks and a right for Whites; something women should consider more seriously than men (Maluleke 1999).

Restitution on the other hand appears more disagreeable, more rough, more divisive and less amenable to taming and down-toning. We are frightened of this term even though it should sound less ominous than the term repossession. Perhaps there is a general suspicion that the two terms are interchangeable. So we avoid the former and detest the latter intensely. The related but not synonymous term "reparation" appeared briefly on our national radar, during the Truth and Reconciliation process (Meiring 1999). But it was never quite embedded into national memory, even less so in the national psyche to the extent that the term "reconciliation" was to become. On hindsight at least, we now know that the weakest aspect of the work of the South African TRC was in the area of reparations (Maluleke 1997b).

A theological approach to restitution is different from a purely legal approach to it. Legally understood, restitution is the provision 
of legal remedy to past wrongs. Here the distinction between restitution and compensation takes particular importance. For example, if a court of law instructs a defendant to provide restitution to a complainant, the general suggestion is that the defendant must give up his/her gains (probably acquired unethically, unfairly, illegally or all of the above) wholly and fully to the claimant. There is a famous African anecdote that says: "When the white man came to Africa, the African had land and the white man had the Bible. The white man said to the African: 'Close your eyes and let us pray.' At the end of the prayer, the white man had the land and the African had the Bible”. Were we to agree that this is an instance of wrongful or illegal acquisition of land and probably also an unethical use of prayer?; should the African in question pursue the matter in a court of law; and should the white man of the fable be ordered to provide restitution. Legally speaking, for restitution to occur, the white man would be required to restore/return the land of the African.

But there are many possible complications with a purely legal approach. First there could be dispute as to whether the acquisition was really, decidedly and deliberately wrongful. Second there could be problems with the altered nature of the object of restoration. The land may have been originally acquired rich and green but returned either nude and arid or worse still returned as a concrete jungle. Another complication comes when the original claimant is no longer alive. The matter may be further complicated when the injury or loss suffered is not reduceable to a concrete and tangible thing. How do we restore such intangibles as integrity, relationships, dignity and reputation? The situation can be equally vexatious in instances where either the existence or type (or both) of original or authentic "proof" of ownership is contested. These complications are partly intended to illustrate some of the difficulties with purely legal notions of ownership, loss and injury (Doxtader and Villa Vicencio 2004).

The ambitious threat I am making behind everything I am saying here of course is that a theological understanding of restitution may help mitigate some of these problems. But restitution is no less complicated and no less disagreeable when viewed theologically. No discipline is more aware of the gap between the ideal and the actual; no discipline is more aware of the virtual impossibility of the restorative measures of mere mortals; no discipline fathoms these difficulties better than theology. If anything, 
theology should be even more skeptical of some of the platitudes not only about reconciliation and restitution but also about human development and nation-building that are part and parcel of the spirit of neo-liberalism. Not that these ideals are invalid or undesirable, but that they are ideals. Ideals which we should do everything in our power to foster claim and pursue for ourselves and for everyone; but never forgetting that they are but mere ideals whose pursuit can be perverted and the access to which can be most unequal (Maluleke 1999).

\section{TOWARDS A THEOLOGY OF RESTITUTION}

\subsection{Theological rationale}

We operate from the assumption that restitution is a desirable and necessary course of action - one which is both contextually and theologically justifiable. Restitution is for us at once a human ideal and a God sponsored objective. The basic intention and outcome of God's revelation is restoration and restitution. In reconciling the world to God self, God also means to restore the world to its originally intended and ultimate state. Restitution is therefore at once an aspect of the doctrine of atonement and a dimension of the doctrine of creation. Restitution is at heart of both Christology and Trinitarian Theology. Even the old legalistic-theological understanding of atonement as ransom, while strange to our modern ears, does highlight the centrality of restitution as an aspect of soteriology.

It is the language with which God bridges the divide between God and creation. It is God's ultimate response to the brokenness of the world and the sinfulness of human beings between and among themselves; between themselves and other creatures and between themselves and God. In this sense the world cries out for restitution and restoration.

To return to the Bible and land fable, restitution is at once about humans; about human interaction; about human relations to the environment; about human use and abuse of prayer (religion) as well as human use and abuse of the Bible. Restitution is about justice, but an expanded notion of justice. Ultimate restitution entails the restoration of just relations between and among humanity, creation and God. When isolating areas in need of restoration and 
restitution we must be able to see the dependencies between various forms of "injustices” and "justices” (McIntyre 1988).

Theologically speaking, God is the author and grand architect and driver of restitution. Ultimately - only God can restore. But we are invited and undertook to participate in restitution both in penitence and in gratitude. In penitence because ultimately none of us are above and beyond restitution - which is why we need to be saved. In gratitude because in spite of the scale of damage we have done to ourselves to others and to other creatures, God still invites and accepts us.

Restitution is therefore not merely a social gospel fad. It is apt for South Africa and South Africans but it is ultimately about the human condition, the world and relations with God. Theologically speaking, restitution, like reconciliation which is facilitative of restitution, is as costly as it is necessary. While "corporate social investment" may facilitate restitution, it should not be confused with it. Similarly while charity - personal and communal charity - may ferment and inspire restitution actions, restitution should nevertheless not be confused with charitable acts. Corporate social investment, like charity may stem from philanthropy emanating from excessive profit and even the desire for even more profit; it may be a corporate marketing ploy; it may even be a strategy to achieve maximum tax savings. Charity, while commendable thrives on and needs the very conditions it seeks to address. Not surprisingly, charity is seldom intended to address root causes, seeking rather to address urgent, illustrative, obvious and excessive symptoms. Charity tends to be merely and only pragmatic. Restitution is different.

Restitution starts with an admission of personal, historical and communal guilt. It starts from an awareness that whatever it is we can do in pursuit of restoration, we must do, and do it NOW. However, even as we do what we can and have to do, we know also that what we do alone will never be enough to effect restoration. We also realise that restoration work spans beyond our sphere of influence and even beyond our life time. This realisation does not send us into the dark cave of apathy; rather it spurs us on because we realise that we have so much restitution to do with little time and scant resources. Charity and corporate social responsibility are often about the giver and the investor, intending them to feel good about 
themselves and intending to make others feel good about the investors and the givers.

But restitution focuses our attention on the injured; whether the injured are the women in our country, the blacks among us, the "foreigners" within "our" borders, the forests of our country, the fish in our oceans or the ozone layer. In short, restitution acts stem from a realization that we owe God so much there is not enough time and wherewithal to pay back. It stems from the realisation that individually and communally, across the generations we have wrought so much havoc and pain and destruction in the lives of other human beings and in the environment we can only do a very little in our attempt to make up for it. It stems from the realisation that while we may not have caused each and every individual injury, we may have indirectly occasioned it, permitted it, not acted against it or benefited from (ill-gotten gains). Restitution is not inspired by narrow, short-term or factional guilt. Restitution is the grateful and joyous response of a penitent sinner who has been "saved by the bell”, clutched from the jaws of death by God's loving kindness.

\section{OUTLINES FOR A RESTITUTION THEOLOGY}

As highlighted earlier above, one of the most elementary steps in the construction of a theology of restitution is the recognition of the array of restitution, non-restitution and anti-restitution theologies that fill the theological landscape - a landscape that spans individual lives, the pews, the pulpit, government, parliament and the treasury. We live at a time where every one speaks the language of either poverty alleviation or poverty eradication. Even the G8 nations inform us - at least in words - that the eradication of poverty is important to them. But achieving economic growth is probably more important to them so their theology is a theology of restitution focused on growth rather than poverty eradication. There is a latent "theology of restitution" behind the South African fiscal policy, which is galvanised by inflation targeting and such interventions as GEAR (Growth, Employment and Redistribution), ASGIsa and JIPSA. These policies and interventions are often couched in terms of their restorative potential - as part of "the war against poverty". For its part, the church remains mainly beholden to "theologies of restitution" of charity and miracle. We have seen an increment of 'miracle theologies' designed to restore people's health, wealth and relations with God. We need to unmask these theologies of 
restitution. They need to be engaged and challenged. Hence only then can an authentic restitution theology be constructed.

As hinted earlier, a theology of restitution is not only or merely about human beings. Humans need to be restoring the environment. We must remember that in the Christian story God sends Jesus into the world because God loves the WORLD. Jesus was sent to the WORLD not merely to human beings. Perhaps that is why He cursed the barren fig tree and calms the raging sea? Perhaps that is why He sent for a donkey before his triumphal entry into Jerusalem? If God so loved the WORLD that God sent Jesus, then we, selfish human beings that we are, may have to contend with the possibility that Jesus did not just die for me, my clan, my race and my gender. Perhaps we ought to stop selfishly singing as we do in our churches that "He is mine, mine, mine, Jesus is mine" as is we as human beings hold sole intellectual property rights over Jesus. Jesus died for the mountains, the fish, and the plants and for the ozone layer too! For God so loved the world! That then is the span and range of restitution of which we speak.

At the human level, the focus of authentic restitution theology should always be on those members of society who are left out - on and off the margins of societal structures and processes - the 'unpeople'. These 'un-people' are those who are unbanked, unemployed, unmedical-aided-people, unskilled, uneducated, unreached; the homeless, the non-citizens, the "hordes" of illegal immigrants, the refugees and the asylum-seeking people who "descend" on cities and villages by boat, car, on foot, by hook or by crook. These are the persons on whom our restitution focus should be.

These people stand out like "ugly warts and blots" in the "enchanting" and "smooth" narrative landscapes of "glorious" stories of "progress", "reconciliation" and "development" not only in our country but in many countries as well. They are the squatter camp dwellers who spoil the "beauty" of the Cape Town landscape and its serene suburbia by installing their dirty, toilet-less, electricity-less and road-less ugly dwellings. These people remain disenchanted and dissatisfied despite living in the "greatest economic boom" South Africa has experienced ever. Discourses like they are the "thankless" people who, primarily because of "their own fault", have "failed to grasp the opportunities" of our times are abundant. These are the people we would rather not see. Such people 
should hide themselves, or else we will find ways and means to keep them hidden. Indeed, we find and devise all sorts of ways and means to hide them away. We do this through our town planning strategies; through the language, we use to describe them; through our policing strategies that ensure that, they constitute the majority in jails; through our economic policies that ensure not only that these people swell the ranks of the unemployed, but also that they constitute the majority in mortuaries. If all these fail, we hide them and refuse to see them in the manner in which we compile and interpret statistics about them.

\section{RESTORING LAZARUS: RESTITUTION THEOLOGY ILLUSTRATED}

"There was a rich man who was dressed in purple and fine linen and lived in luxury every day. At his gate was laid a beggar named Lazarus, covered with sores and longing to eat what fell from the rich man's table. Even the dogs came and licked his sores. The time came when the beggar died and the angels carried him to Abraham's side. The rich man also died and was buried" (Luke 16:19-22 [NIV]).

\subsection{An Africanist reading of the story of Lazarus and the rich man}

As far as I can gather, the New Testament has two notable Lazaruses. Both are infamous characters. One is a character in real life and the other is a fictitious character in a parable. Both acquire their fame in and through death. The one is a friend of Jesus the other a friend of no one. The one is rescued from death by the intervention of Jesus. The other dies of hunger and sores and goes to heaven. Both Lazaruses are miserable. The Lazarus who was not rescued from death - the one who was allowed to die - might yet give us some pointers to restitution. This is the Lazarus of Jesus' parable in Luke 16. Parables are an established rabbinic teaching device. They are fictitious, but very familiar everyday stories through and behind which rabbis were able to make the teaching of abstract virtues and morals more practical and tangible. Jesus used this and related teaching devices very effectively.

In relation to the parable of Lazarus and the rich man, I propose an Africanist contemporary reading. An Africanist contemporary reading is one I have encountered repeatedly in African 
church settings. This kind of reading is the basis of the communal preaching strategies employed in many African church settings. There a text is read and person after person stands up (sometimes they stand up in pairs ${ }^{1}$ ) to "respond" to the text and testify to what the text "does" to them. Several principles govern such an approach. One such principle is that effective reading and insight comes out of a joint and communal effort. Therefore, the various responses of individuals and pairs of individuals, in concert with the audience, are not isolated self-standing sermons, but aspects of a long communal and incremental sermon. Another principle in such a reading is to take the text (in this case the parable) most seriously so much so that it appears to be taken literally.

Nevertheless, serious readings should not be confused with literal readings. Serious readings, while aware that the text may be fictional, choose to read the text as if it were "true". With the tools of language, culture and interpretation at their disposal, the readers will "share" the various meanings, issues and questions raised, embedded in and invoked by the text. In this way, Africanist readers pay very close attention to details in the text.

An equally important principle is to read the text not by means of "othering" and "deferment" but to read it "as if it was written for me". The ultimate question here is: what does the text say to and about me? Participants in communal reading are not "allowed" to prescribe the meaning of a text to others until they have worked out what it says to and about themselves. It is only via the personal, that implications and prescriptions can be worked out for others. An equally important principle is the principle of imaginative dramatisation. A text has to be brought to life. This is often done through the voice and gestures of the reader and preacher. The aim of such voicing and gesturing is to let the full light of the text shine on the reader. Readers often allow themselves to inhabit the

1 When two people respond to the text as a pair, the ostensible purpose is for consecutive interpretation from the one language to another, e $g$ the preacher will speak in Isizulu and the interpreter will translate into Sesotho i e the one stands up to provide interpretation. However as often happens, the interpreter does more than linguistically translate, they also bring their own layer of response behind and underneath the "voice" of the preacher. As a result, what the audience gets are two sermons in the guise of one. 
characters and tendencies referred to or invoked in the text. The drama of the text is replayed before all at sundry.

A final principle of communal Africanist reading is the reading of silences. Such readings take many forms. They can take the form of questions about silences they can also take the form of imaginative filling in of the gaps. A reader of the parable of the prodigal son may, for example spend time, wondering how and where the mother of the prodigal son was. These are some of the principles with which I offer a reading of the parable of Lazarus and the rich man.

\subsection{Reading the story for restitution}

In the rich man and Lazarus parable, Lazarus interrupts, spoils and aggravates what could otherwise have been a flowing and innocent narrative about a very rich man - probably a hard-working and strategic rich man. Lazarus comes and installs his smelly, soresmitten and flea-ridden body in the front gate of the rich man's homestead. In this way, Lazarus "exposes" himself to all who come in and go out of the rich man's homestead. However, in positioning himself thus, Lazarus also "exposes" the rich man. By his action, he casts doubts on the morality and ethics of the rich man. His presence in the street poses questions about the justness of the larger society in which he and the rich man live.

Yet we cannot resist the temptation to reduce the meaning and message of Lazarus. Surely, there were richer and more evil men in that town? Why pick on this particular poor Rich Man? Surely, there were colonies and squatter camps in which he could have gone to live. Surely, there were also men poorer than Lazarus either who wore their poverty with dignity or who simply worked harder to improve their lot in life? Why could he not wear his poverty with dignity and why did he not work harder to improve his lot?

\subsubsection{The contrasts}

The contrast between Lazarus and the nameless rich man is too stark not to arouse our curiosity. In three relatively short sentences, we are introduced to two contemporaries who nevertheless could not be more different. The one is so rich he does not need to have a name his riches define and announce him wherever he goes. The other is so poor all he has is a name and a body full of sores. The one is so rich he is surrounded by servants, friends and family; the other is so 
poor only dogs see some use in him. The one is so rich he lives in luxury everyday; the other is so poor he lives on his dreams and hopes and fantasies spurred by the smell of good food coming out of the windows of the rich man's house. The two of them bring to mind, the words of one Bob Marley song: "Some people have ways and means. Other people have hopes and dreams". The profession of the one is to be rich while the profession of the other is to be beggar. Yet these two persons are contemporaries, living in the same world, citizens of the same country, residents of the same city, neighbours, on the same street! Or should we say the one lives and the other survives? For all we know, they might have gone to the same primary school. However, the one lives in a house and the other is a street beggar.

The contrast between them is too stark to be explained merely as accidental or merely in terms of personality and individual traits. What are the economic, cultural and developmental systems that manufacture such contrasts? Where are they located? What is the "factory" that produces such contrasts? Above all, now that we have Lazarus, how can we restore him? Can Lazarus be restored? What restitution accrues to Lazarus? Is Lazarus worth restoring? Can we do better than the dogs which lick his wounds?

\subsection{How to restore Lazarus: six proposals and considerations}

\subsubsection{Seeing Lazarus}

In order to restore Lazarus we must see Lazarus. Lazarus is difficult to see. As hinted earlier on, many resources are spent trying to hide away from our Lazaruses or to hide our Lazaruses away - to reduce their meaning, obscure their presence and to explain them away so that they have no observable human face. We go out of the way to explain away, misrepresent and criminalise the anger of our Lazaruses. Lazaruses may be walking our streets, living next door, but they are hard to see. As Jesus said: "There are none as blind as those who will not see". The first and most important functions of restitution theology is to enable Lazaruses to be seen.

\subsubsection{Lazarus is an emergency}

In order to restore Lazarus, we must not bank on the patience and the discipline of Lazarus. We must not assume that Lazarus will "always be there" and we must not assume that Lazarus will always be like "that". That he sits there, smells the good food, and still just sits 
there is the real miracle in this story. In real life such Lazaruses have become fewer and far between. Our plans for restoring Lazarus must assume that Lazarus will lose patience - the only thing he has to lose! Our plans must be decisive and urgent. Indeed we have seen Lazaruses "disrespecting" national borders and private perimeter fences. Restitution is an urgent task for implementation and not merely reflection! Restitution theology must therefore be undertaken with a sense of urgency.

\subsubsection{Recognise the link}

There is a link between the poverty of Lazarus and the wealth of the rich man. While daily soup packet and left-over bread from the table of the rich man will keep Lazarus going, Lazarus will need more than soup packets and left-overs to be restored. Lazarus will only have been restored once the plane-fields have been levelled enough for him to fend for himself. It is therefore important that we have a good grasp of all the things which keep Lazarus at the gates of the rich man's homestead, begging and sniffing for food. We must unmask and seek to break the linkages between Lazarus's abject poverty and the rich man's filthy wealth. This is the "dirty work" that restitution theology must do, not only in relation to Lazaruses and rich men, but in relation to men and women, blacks and whites, foreign nationals and citizens, human beings and the environment.

\subsubsection{Lazarus must be consulted}

For Lazarus to be restored Lazarus must be engaged and Lazarus must be involved. Lazarus has a history, a context, a story and a culture. Lazarus was not born at the gates of the rich man's homestead! Circumstance and survival have propelled him to the door of the rich man's house. Though brutally victimised, Lazarus is an agent who is not only intelligent but knows what needs to happen for him to be restored. The task of restitution theology is not so much to speak for Lazarus or even speak down at him (in the guise of speaking with him) - a mistake so many well-meaning theologies have committed before but to listen to Lazarus. Our task is not so much to feel pity for Lazarus but to acknowledge his presence and hear his message. This is the stuff of restitution theology.

\subsubsection{Recognizing Lazarus's initiative}

By positioning himself strategically at the gate of the rich man's house, in that wealthy suburb in which the rich man lives, Lazarus 
has already shown exceptional initiative. The sandal of Lazarus's presence in the rich man's gates is that it took guts and intelligence to reach that spot and yet all he gets after all the trouble is "to yearn for crumbs". Similarly, the "Lazarus" of John 5, manages to get himself to the banks of the pool of Bethesda, one of the only places he was sure to get help. Lazarus will bring himself to the brink of salvation, but like the rest of humanity, Lazarus cannot save himself - he needs help in order to compete when the waters are stirred! It is not that Lazarus is lazy, but there is a limit to what he as an individual can do to deal with the barriers that have been put on his path. Furthermore, given the ruthless competition that ensues between the Lazaruses every time opportunities for advancement occur, Lazaruses need help. The problem is not one of lack of initiative among the Lazaruses, but of too much initiative among a group having its space and scope deliberately limited. The task of restitution theology is to valorise both the initiative of Lazarus as well as the limitations it faces.

\subsubsection{Before Lazarus dies}

There is a widespread tendency to read the story of Lazarus by focusing on what happens to Lazarus after death. Indeed, in Luke 16, the parable is itself told mainly from the point of view of what happens after death. In this way, the story is reduced to some anecdote about life on the other side of the grave. But Lazarus must be restored BEFORE he dies not AFTER he has died. Lazarus must be restored in this life and not in the hereafter. We must do our part and let God do God's part. Lazarus must be helped so that he does not die needlessly and prematurely.

Depending on one's understanding of global economics, the death of Lazaruses is not necessarily bad for the economy, the revolution and even the GDP. We live in a country where premature and widespread death is itself becoming both a lucrative industry and a way of living (Maluleke 2002). The task of restitution theology is to intervene on this side of the grave and to deal with the challenges Lazaruses face this side of the grave. On the agenda of restitution theology we will feature such items as, HIV/AIDS, violence against women, and poverty eradication.

\section{Consulted literature}

Biko, S 1988. I write what I like. London: Penguin. 
Doxtader, E and Villa Vicencio, C 2004. To Repair the Irreparable. Reparation and Reconstruction in South Africa. Cape Town: David Philip.

Maluleke, T S 1995. Black Theology Lives! On a Permanent Crisis. Journal of Black Theology in South Africa 9(1), 1-30.

-, 1997a. Truth, national unity and reconciliation in South Africa: aspects of the emerging theological agenda. Missionalia 25(1), 59-86.

-, 1997b. Dealing lightly with the wound of my people? : The TRC process in theological perspective. Missionalia 25(3), 324-343.

-, 1999. The Truth and Reconciliation Discourse: A Black Theological Evaluation, in Cochrane, J, De Gruchy J \& Martin, S (eds), Facing the Truth: South African Faith Communities and the Truth Commission, Cape Town: David Philip, 101-13.

-, 2002. Of collapsible coffins and ways of dying. Ecumenical Review 54(3), 313-332.

-, 2007. Of lions and rabbits: The role of the church in reconciliation in South Africa. International Review of Mission 96, 380.

McIntyre, A 1988. Whose Justuce? Which Rationality. Notre Dame: University

Mbiti, J S 1966. Akamba stories, (S.I): Clarendon Pr.

-, 1970. Concepts of God in Africa. London: S.P.C.K.

-, 1986. Bible and theology in African Christianity. Nairobi: Oxford University Press.

Meiring, P G J 1999. Chronicle of the truth commission: a journey through the past and present-into the future of South Africa. Vanderbijlpark: Carpe Diem.

Mosala, I J 1989. Biblical hermeneutics and black theology in South Africa. Grand Rapids, Mich: Wm.B.Eerdmans.

Motlhabi, M B G 1994. African theology or black theology?: toward an integral African theology. Journal of Black Theology in South Africa 8/2, 113-141.

Okullu, H 1974 Church and Politics in East Africa Nairobi: Uzima Press.

Schreiter, R J 1985. Constructing local Theologies. London: SCM Press.

Setiloane, G M 1976. The image of God among the Sotho-Tswana. Rotterdam: Balkema. 